\title{
Contextualizing Anti-Immigrant Attitudes of East Europeans
}

\author{
Nina Bandelj ${ }^{1} \&$ Christopher W. Gibson ${ }^{2}$ \\ ${ }^{1}$ Professor of Sociology, University of California, Irvine, USA \\ ${ }^{2}$ Assistant Professor of Sociology, California State University, Fullerton, USA \\ Correspondence: Nina Bandelj, Professor of Sociology, University of California, Irvine, USA
}

Received: May 14, 2020 Accepted: July 27, 2020 Online Published: August 5, 2020

doi:10.5539/res.v12n3p32 URL: https://doi.org/10.5539/res.v12n3p32

\begin{abstract}
This article examines attitudes toward immigrants by analyzing data from the 2010 and 2016 waves of the EBRD's Life in Transition Survey among respondents from 16 East European countries. Logistic regressions with clustered standard errors and country fixed effects show significantly higher anti-immigrant sentiments after the 2015 immigration pressures on the European Union borders compared with attitudes in 2010. Almost two thirds of the respondents agreed in 2016 that immigrants represented a burden on the state social services, even when the actual immigrant population in these countries was quite small. In addition, East Europeans expressed greater negative sentiments when the issue of immigration was framed as an economic problem — a burden on state social services - than as a cultural problem - having immigrants as neighbors. On the whole, these results point to the importance of contextualizing anti-immigrant attitudes and understanding the effect of external events and the framing of immigration-related survey questions.
\end{abstract}

Keywords: immigration attitudes, Eastern Europe, migrant crisis, economic threat, cultural boundaries

\section{Introduction}

Across the world, recently elected leaders have garnered support from nationalist and populist movements, including in Russia (Grigoryan \& Ponizovskiy, 2019), Hungary and Poland (Bandelj \& Finley, 2019), the United States (Baker, Perry, $\&$ Whitehead, 2020), and Brazil (Schmidt \& Quandt, 2018). Nationalism and populism are often accompanied by the stoking of anti-immigrant hostility (Bonikowski, 2017), raising questions of when and how people express negative attitudes toward immigrants. In this article we ask, how much do anti-immigrant sentiments depend on context and external events, such as the increased pressure on European borders that followed the 2015 refugee crisis? Moreover, does expression of hostility depend on whether immigration is presented as an economic problem, such as immigrants taking economic resources from native citizens, or as a cultural one, such as immigrants threatening the natives' ways of life?

This paper tackles these questions in the context of 16 East European countries that were a part of the former socialist bloc. This region is a key location to study anti-immigrant attitudes because the recent wave of nationalism in Europe can be traced to Hungarian leader Viktor Orban, who rose to power in 2010 and who has adopted a strong anti-immigrant stance and has defied democratic principles of governance (Scheppele, 2014). Available cross-national public opinion reports suggest that the level of anti-immigrant hostility expressed by Hungarians is not unique among East Europeans and that the East European region scores among the lowest in the world on migrant acceptance (Ray, Pugliese, \& Esipova, 2017). ${ }^{1}$

This study uses data from the European Bank of Reconstruction and Development (EBRD) Life in Transition Survey (LITS) (EBRD, 2020), which includes information that is well suited to examine the extent of people's anti-immigrant sentiments across 16 East European countries included in the dataset. The available data allow for a comparison of anti-immigrant sentiments at different points in time and for different question frames. Specifically, the analyses reported in this paper employed logistic regression models with country-level fixed effects in 2010 and 2016, before and after the 2015 migration pressures, for two questions in the LITS that capture anti-immigrant sentiments (AIS): [1] agreement with the statement that one does not want to have immigrants as neighbors, and [2] agreement with the statement that immigrants are a burden on the national social protection system. The first question frames immigration as a cultural problem, trying to capture prejudice stemming from perceived threats to ways of life from the close presence of

\footnotetext{
${ }^{1}$ In the 2017 World Gallup Poll of 142 countries, nine of the 10 countries with the lowest Migrant Acceptance Score are East European. Hungary's score is the lowest, 1.69 from a total of 10. The average score for Eastern Europe is 2.77. In comparison, the United States scores 7.86, and the most immigrant-accepting countries are New Zealand and Iceland with scores of 8.25 and 8.26 respectively (Ray et al., 2017).
} 
immigrants. In contrast, the second question frames immigration as an economic problem, suggesting that immigration is economically costly because it requires the state to provide social services to immigrants.

This article advances our understanding of attitudes toward immigrants by examining how expressions of hostility may be malleable and context dependent. In particular, we examine how anti-immigrant views depend on external circumstances that heighten moral panics (Goode \& Nachman, 1994) and on perceptions and notions of moral worth and deservingness (Lamont 1992) that may be specific to socio-cultural contexts, such as postsocialist transformations (Bandelj 2016). Research on the drivers of immigration-related perceptions often uses single or composite indicators of AIS and focuses on predictor variables that align with notions of perceived economic threat on the one hand (e.g. Gerber, Huber, Biggers \& Hendry 2017), or notions of cultural prejudices grounded in the us versus them dynamics (e.g. Quillian 1995), on the other hand. Propelling this discussion forward, we demonstrate that it is also the framing of the immigration problem -- either as an economic or as a cultural problem -- that affects people's expressed attitudes. This is because salience of various criteria of worth, or the yardstick by which people evaluate the worth or deservingness of others, is culturally specific (Lamont 1992). By contextualizing anti-immigrant attitudes around external events and question framing, we bring the field of immigration into conversation with studies in cultural economic sociology (Wherry, 2012; Zelizer, 2011), social construction of postsocialist transformation (Bandelj, 2016; Hann, 2002) and moral dimensions of economic phenomena (Fourcade \& Healy, 2007; Frye, 2012; Hilmar, 2019; Young, 2004).

The results of our study show, first, a very pervasive expression of anti-immigrant sentiments among residents of the East European countries included in the study, and second, that those sentiments significantly increased from 2010 to 2016 . For instance, an average of two thirds of the respondents in the representative samples from the 16 countries agreed that immigrants were a burden on state social services in 2016. These results can be linked to exogenous events, specifically, the migration from the military conflict-ravaged Middle East to the European Union (EU) in 2015 (Eurostat, 2018 ), and the political backlash from East European governments to the EU directives to accept refugee quotas (Baczynska, 2017; Kosztolanyi \& Cullen, 2018).

Moreover, the results show that expressions of AIS depended on how questions about immigration were framed. East Europeans expressed more AIS when immigration was presented as an economic problem (i.e. a burden on the social protection system) rather than as a cultural problem (i.e. dislike of having immigrants as neighbors). In addition, respondents who perceived themselves to be economically vulnerable (having a low economic standing or being unemployed) were much more likely to view immigrants as an economic burden. In contrast, a respondent's economic status was not significantly linked to AIS when immigration was framed as a cultural problem. Therefore, AIS tended to be malleable, depending on question framing and on the salience of economic considerations. The next section of this paper provides some background to the study of immigrant attitudes in Eastern Europe. After, we draw upon previous research to identify relevant determinants of immigration attitudes that are the focus of our study: a) external events, specifically the 2015 European migration pressures, and b) individual-level characteristics that influence how people perceive immigrants. Based on this literature review, we derive hypotheses to test in our study. The second part of the paper presents the data, methods of analysis, and discussion of the results. The conclusion identifies the contributions this study makes to an understanding of anti-immigrant hostility and its broader societal implications.

\section{Background}

In an editorial that introduces a special edition dedicated to attitudes towards immigrants in European nations, Davidov and Semyonov (2017) remind us that immigration to Europe has a long history with temporally dynamic push and pull factors, and that integration policies and levels of public support vary dramatically across countries. Nevertheless, contemporary studies on attitudes towards immigrants demonstrate widespread anti-immigrant sentiments throughout Europe (Davidov, Meuleman, Billiet, \& Schmidt 2008; Meuleman, Davidov, \& Billiet, 2009; Semyonov, Raijman, \& Gorodzeisky, 2008). In recent years, scrutinizing this phenomenon has reached hightened relevance. Economic anxieties and rising inequality (Andersen \& Bjørklund, 2016; cf. Kitschelt \& McGann 1995), as well as cultural backlash (Norris \& Inglehart, 2019) has led to increased support for right-wing populist authoritarian movements and xenophobic political parties, which have strong anti-immigrant stances. An investigation into immigration is thus linked to the rise of nationalism, which is a political project but also "a pervasive cognitive and affective orientation" that animates "everyday politics in contemporary democracies" (Bonikowski, 2016, p. 428). These "everyday politics" include how individuals, not only politicians, perceive insiders and outsiders of the nation, especially immigrants.

Nationalism and ethnic tensions are not new to the East European region (Bandelj \& Finley, 2016; Zubrzycki, 2001). Indeed, comparative research shows that ethnically oriented nationalism, which is hostile to non-natives, is stronger in Eastern Europe than in Western Europe (Ariely, 2013; Ceobanu \& Escandell, 2008). Scholars also show that economic discontent (Bandelj \& Finley, 2019) and income inequality (Mahutga \& Bandelj, 2009; Bandelj \& Mahutga, 2010) in Eastern Europe has been increasing for multiple decades and cannot be attributed solely to post-2008 financial 
crisis-related economic downturns (Bandelj \& Finley, 2019). Taken together, these studies underscore the importance of understanding immigrant attitudes in Eastern Europe in the context of fundamental transformations of socio-economic systems after the collapse of communism in Eastern Europe (Hann 2002). In particular, this research points to a need for a relational account of the ways in which natives make sense of their position in society relative to immigrants, and the new salience of economic worth in evaluating who is a deserving member of society (Hilmar 2019). Against this backdrop, the next section draws upon previous research to identify relevant factors that influence immigration attitudes: a) external events, specifically the 2015 European migration pressures, and b) individual factors that shape how immigrants are perceived.

\section{External Events as Predictors of Attitudes: The 2015 European Migration Pressures}

The 2015 European migration flows, also called the 2015 European refugee crisis (Chouliaraki, Georgiou, \& Zaborowski, 2017), refers to the significant increase in asylum seekers arriving in Europe from various routes between late 2014 and 2016. From 2014 to 2015, the number of asylum applicants rose from 626,960 to 1.3 million (Eurostat, 2018). Fleeing the wars in Syria, Iraq, and Afghanistan, nearly 2 million refugees settled in Turkey alone, according to the United Nations High Commissioner for Refugees (Berry, Garcia-Blanco, \& Moore, 2015). As many attempted to cross the Mediterranean to Greece, overcrowded boats capsized, and the death toll rose to more than 1,300 (Berry et al., 2015).

The EU responded with measures to alleviate the burden of border states' having to handle all asylum applicants at the national level (Smale \& Eddy, 2015). Two measures contributed to this burden. First, the Schengen Agreement abolished passport border checks within the EU and for some Free Trade Association member states and, instead, reestablished passport checks on the outer boundaries of the border states, such as Hungary's and Croatia's borders with Serbia (European Commission, 2020b). Second, the Dublin Regulation (European Commission, 2020a) mandated that the state in which an asylum application is initially filed is responsible for that application (DG Migration and Home Affairs, 2015; European Parliament, 2018). Thus, several less affluent EU border states faced the responsibility for this unexpected influx of applicants. When the photo of a 3-year-old Syrian boy, Aylan Kurdi, who was found dead on the shore of Turkey, was displayed on media cover pages around the world (Fallon, 2018), calls for aid from the public increased, and the situation was framed as a humanitarian crisis (Berry et al., 2015).

In response, the European Commission introduced the European Agenda on Migration in May 2015, which called for EU member states to share the burden of relocating asylum seekers (Eurostat, 2018). However, the directive was met with a backlash. Poland, Hungary, and the Czech Republic refused to accept their quotas of asylum seekers, citing concerns that the migrants, mostly Muslims, would not fit into their societies and could bring violence from Islamic militants (Baczynska, 2017). As a result, Germany and Sweden took a disproportionately large number of refugees in an attempt to follow the EU directive (Eurostat, 2018), and a rift arose between these older EU member states and the newer members from Eastern Europe (Kosztolanyi \& Cullen, 2018).

The arrival of refugees and migrants to Europe in 2015 elicited a wide-scale discourse in the media, ranging from calls for national and transnational humanitarian efforts to calls for protective measures for countries' citizens (Chouliaraki \& Zaborowski, 2017). The complex situation was framed in the media as a crisis (Zaborowski \& Gregoriou, 2019, p. 94). Scholars in the Department of Media and Communication Studies at the London School of Economics and Politics (LSE) examined 1,200 news articles from eight countries and identified three key events in media portrayals of this phenomenon in 2015: a) Hungary's construction of a physical barrier along its borders with Serbia on July 13, b) the drowning of the 3-year-old Syrian boy off Turkey's coast on September 3, and c) the terrorist attacks in Paris on November 13.

Against this backdrop, we examine the 2015 immigrant pressures on EU borders as a major contextual factor with which to understand anti-immigrant sentiments among East Europeans. Research shows that media capitalizes on external events to frame issues to the public (Brummett, 2014; Chomsky, 1997; Markham \& Maslog, 1971), often creating moral panics (Goode \& Nachman, 1994). The 2015 European immigration pressures were described as a crisis (Bellardi, Busch, Hassemeer, Peissl, \& Scifo, 2018; Chouliaraki et al., 2017; Chouliaraki \& Zaborowski, 2017; Zaborowski \& Georgiou, 2019), and therefore, we would expect to see exacerbated fears of immigrants among East Europeans after 2015, compared with an earlier period. Moreover, East European governments loudly voiced opposition to mandated quotas of refugees (Baczynska, 2017; Kosztolanyi \& Cullen, 2018), which likely legitimated residents' anti-immigrant hostility. Therefore, we expect that AIS in 2016 are significantly higher compared with AIS in 2010 (Hypothesis 1).

In addition to immigrant pressures on European borders, we seek to examine the role of individual determinants on AIS. Previous research has distinguished between considering immigrants as an economic threat and as a cultural/society/lifestyle threat. The next section reviews these two bodies of research.

\section{Individual-Level Predictors of Attitudes}

Why do individuals express anti-immigrant sentiments? One prevalent perspective emphasizes the potential economic 
threat that immigrants present to natives based on realist conflict theories (Polavieja, 2016). These theories suggest that a certain level of economic competition between natives and immigrants for scarce jobs will lead natives to react negatively to immigrants (de la Garza, DeSipio, Garcia, Garcia, \& Falcon, 1992; Palmer, 1996; Simon, 1993). Therefore, researchers have often operationalized this economic threat with factors like household income, unemployment status (Meuleman et al., 2009), and labor market positioning (Coenders \& Scheepers, 2008; Polavieja, 2016) and have found a correlation between an individual's lower economic standing and higher AIS. Therefore, we expect that an increase in economic standing of a respondent is negatively associated with expressed AIS (Hypothesis $2 A$ ). Moreover, we expect that being unemployed is positively associated with AIS (Hypothesis 2B).

Research on the impact of economic conditions is extensive (Gorodzeisky \& Semyonov, 2009; Quillian, 1995; Schneider, 2008; Semyonov, Raijman, \& Gorodzeisky, 2006; Wilkes, Guppy, \& Farris, 2008; Wilkes \& Corrigall-Brown, 2011), but some findings are mixed. For instance, using quantitative analyses, Sides and Citrin (2007) found that a country's GDP affected anti-immigrant sentiments, but unemployment rates did not (for an alternative view, see Coenders \& Scheeper, 2008). Facchini and Mayda (2009) showed that in countries where immigration is unskilled, respondents' income was negatively correlated with pro-immigration attitudes; however, in countries where immigration is skilled, income was positively correlated with pro-immigration attitudes. These findings highlight the importance of local contexts and temporal circumstances in understanding the effect of economic conditions on anti-immigrant hostility.

Moreover, whether an individual respondent perceives immigrants as an economic threat could depend not simply on objective economic realities, but on how survey questions are framed (Benford \& Snow, 2000) to make the economic considerations more or less salient. For example, if questions explicitly emphasize immigrants as an economic threat, we would expect respondents' economic position to be a relevant indicator of their answers. However, if questions about immigrants do not have explicitly economic connotations, such as those asking about having immigrants as neighbors, then respondents' economic position would likely be less relevant to their answers. Therefore, we expect that a higher economic standing of a respondent is negatively associated with expressed anti-immigrant sentiments for economic but not cultural questions about immigrants (Hypothesis 3A). Likewise, we expect that being unemployed is positively associated with AIS (Hypothesis 3B) for economic but not cultural questions about immigrants.

In addition, previous research has identified non-economic predictors of anti-immigrant sentiments, which are included as controls in our regression analyses. For example, individuals often draw symbolic boundaries, or notions of "us versus them" that majority groups use to distance themselves from minority groups (Bail, 2008; Lamont \& Molnár, 2002; Tilly, 2004). This symbolic boundaries perspective draws attention to the role of nationalist tendencies and cultural divisions (Brubaker, 1992; Ceobanu \& Escandell, 2008; Coenders \& Scheepers, 2008; Ceobanu \& Escandell, 2010; Fetzer, 2000b; Hjerm, 1998; Pehrson, Vignoles, \& Brown, 2009) and the effects of minority status (Hayes \& Dowds, 2006) and religiosity (Bohman \& Hjerm, 2013) on immigration attitudes. Therefore, we sought to account for respondents' religious identification and ethnic affiliation. Using available data, we controlled for whether respondents identified as Christian or Muslim, a relevant distinction because the common impression after the 2015 events was that immigrants were Muslim (Chouliaraki et al., 2017). We also included whether respondents belonged to an ethnic minority because research points to the link between immigrant attitudes and nativism (Bonikowski, 2016, 2017; Brubaker, 2017; Kesic \& Duyvendak, 2019).

Furthermore, studies have found that anti-immigrant sentiments are negatively associated with higher educational attainment (Chandler \& Tsai, 2001; Coenders \& Scheepers, 2003; Hainmueller \& Hiscox, 2007; Hjerm, 2001; Mayda, 2006) and with residing in an urban rather than rural locale (Pichler, 2010; Gorodzeisky \& Semyonov, 2016), as urban residents are generally exposed to more diversity than rural persons (Schneider, 2008; Semyonov \& Glikman, 2009). Therefore, we also controlled for education and residence.

\section{Data and Methods}

\subsection{Data: Life in Transition Survey}

To investigate the determinants of immigration sentiments, we used the Life in Transition Survey (LITS), a cross-national survey administered by the European Bank for Reconstruction and Development (EBRD) and the World Bank. The LITS, which was conducted in three waves in 2006, 2010, and 2016, is commonly used by social scientists to investigate economic, political, and social issues related to the post-communist transition (e.g. Anderson, 2017; Bandelj, 2016; Bandelj \& Finley, 2019; Cojocaru, 2014a, 2014b; Cojocaru \& Diagne, 2015; Djankov, Nikolova, \& Zilinsky, 2016; Guriev \& Melnikov, 2018; Habibov, Auchynnikava, \& Luo, 2019; Korosteleva \& Stepien-Baig, 2020; Nikolova \& Sanfrey, 2016; Sanfrey, 2013; Schneider, 2017; Spoor, Tasciotti, \& Peleah, 2014; Tertytchnaya, Vries, Solaz, \& Doyle, 2018; Tkalec, 2020). To investigate the impact of the 2015 European migrant crisis, we used data from the 2010 and 2016 waves. We acknowledge that these data are somewhat limited in their scope and ability for cross-regional research. While they offer an opportunity for robust analysis within this sample of countries in Eastern Europe, we are unable to make 
conclusive comparisons with Western European countries because LITS provides only a small subsample of those, and different countries at different points in time. Further, by centering the study on 16 countries, we confront the methodological limitation of lacking the degrees of freedom that could allow testing of hierarchical models that can account for cross-national variation in addition to individual-level variation. We address this issue by modeling country-level fixed effects in regression analyses.

\subsection{Sample}

As a large-N survey that covers all countries in Eastern Europe and Eurasia, the LITS dataset is ideally suited to answer this study's research questions. We included data from 16 East European countries: Albania, Bosnia and Herzegovina, Bulgaria, Croatia, the Czech Republic, Estonia, Hungary, Latvia, Lithuania, Macedonia (FYROM), Montenegro, Poland, Romania, Serbia, Slovakia, and Slovenia. Eurasian countries not impacted by the 2015 migrant crisis in a comparable manner to the East European countries were excluded. The sample included approximately 1,000 respondents for each country in 2010 and approximately 1,500 for each country in 2016. The total number of respondents for all 16 countries included was 17,554 in 2010, and 24,106 in 2016. All country samples were nationally representative.

The selection of East European countries is strategic because previous assessments have shown a persistent presence of above average AIS in the region, making it a compelling site to understand anti-immigrant attitudes. Moreover, the region has recently experienced a significant receptivity to ethno-nationalist and populist messages, making the issue of immigrant attitudes particularly important for understanding contemporary political developments. In addition, pronounced anti-immigrant sentiments contribute to broad variation in the dependent variables of interest, allowing for robust statistical analysis of a range of individual-level independent variables.

\subsection{Methods: Logistic Regressions With Clustered Standard Errors and Country Fixed Effects}

The two survey questions about immigrant attitudes used as dependent variables in this study were measured as dichotomous outcomes. (See Appendix 1 for a detailed description of all variables and their corresponding survey questions.) Therefore, we conducted logistic regressions with clustered standard errors and country fixed effects (since the data combined respondents across different countries). Fixed effects account for time invariant features that may be related to specific country characteristics that influence economic attitudes in those countries, such as aggregate economic growth, unemployment levels, or demographic structure. The use of fixed effects reduced potential bias in the estimates of individual-level factors without the opaqueness created by variability in national contexts.

Many studies on anti-immigrant sentiments use hierarchical models for analysis to estimate the effects of both countryand individual-level characteristics; however, we chose not to do so for two reasons. First and foremost, our central research questions concern the influence of individual-level predictors and not country-level characteristics. Second, 16 countries is too small a number for a rigorous test of several identifiable country characteristics. Instead, to account for the general influence of country level characteristics, we fit country fixed effects and clustered standard errors into our logistic regression models, which allowed us to focus on individual-level predictors.

Table 1. Descriptive statistics for all dependent and independent variables, by year

\begin{tabular}{|c|c|c|c|c|c|c|c|c|}
\hline & \multicolumn{4}{|c|}{2010} & \multicolumn{4}{|c|}{2016} \\
\hline & Mean & SD & Min & Max & Mean & SD & Min & Max \\
\hline \multicolumn{9}{|l|}{ Attitudes towards immigrants } \\
\hline Do not want as neighbors & 0.133 & 0.338 & 0 & 1 & 0.216 & 0.437 & 0 & 1 \\
\hline Are social protection system & & & & & & & & \\
\hline burden & 0.389 & 0.475 & 0 & 1 & 0.535 & 0.494 & 0 & 1 \\
\hline \multicolumn{9}{|l|}{ Economic characteristics } \\
\hline Economic Standing (Low to & & & & & & & & \\
\hline High) & 4.767 & 1.717 & 1 & 10 & 5.018 & 1.653 & 1 & 10 \\
\hline Unemployed & 0.0526 & 0.27 & 0 & 1 & 0.0267 & 0.175 & 0 & 1 \\
\hline \multicolumn{9}{|l|}{ Other Covariates } \\
\hline Ethnic minority & 0.0626 & 0.35 & 0 & 1 & 0.0743 & 0.369 & 0 & 1 \\
\hline Christian & 0.754 & 0.45 & 0 & 1 & 0.819 & 0.44 & 0 & 1 \\
\hline Muslim & 0.0246 & 0.294 & 0 & 1 & 0.022 & 0.303 & 0 & 1 \\
\hline Education & 3.104 & 1.279 & 1 & 6 & 4.343 & 1.702 & 1 & 8 \\
\hline Urban & 0.64 & 0.482 & 0 & 1 & 0.715 & 0.495 & 0 & 1 \\
\hline Age & 51.55 & 17.40 & 16 & 99 & 49.13 & 17.67 & 18 & 95 \\
\hline Female & 0.596 & 0.494 & 0 & 1 & 0.519 & 0.498 & 0 & 1 \\
\hline Married & 0.621 & 0.486 & 0 & 1 & 0.637 & 0.495 & 0 & 1 \\
\hline Media consumption & 6.738 & 0.733 & 1 & 7 & 6.633 & 0.793 & 1 & 7 \\
\hline Total observations (N) & 22618 & & & & 27085 & & & \\
\hline
\end{tabular}




\subsection{Dependent Variables: Measuring Anti-Immigrant Sentiments}

We ran tests on two survey items in the dataset which seemed best able to tap into a respondent's opinion of immigrants. The first item measures whether immigrants are people whom the respondent "would not like to have as neighbors." The second gauges whether "immigrants are a burden for the national social protection system" (See Appendix A for the specific wording of the questions and Table 1 for descriptive statistics.) These two survey questions capture two different framings of AIS: as a cultural problem and as an economic one. The issue of rejecting immigrants as neighbors reflects how much respondents seek to disassociate from the cultural "other," and the issue of immigrants as being a burden on social protection systems emphasizes economic concerns. Some studies aggregate different immigration questions into an index (Marozzi, 2016), but we purposely chose to analyze them separately in order to examine explicitly whether question framing produced different results.

\subsection{Independent Variable: Measuring Temporal Changes}

We also hypothesized that AIS levels in 2016, following the so-called European immigration crisis, would be significantly greater than those in 2010. In regression models we can test this with a dichotomous variable that indicates whether observations are from 2016, with 2010 as the reference category. If respondents expressed significantly higher AIS in 2016 , then the coefficient for the 2016 variable would be statistically significant.

\subsection{Independent Variables: Two Measures of Economic Characteristics}

We included in the analysis two survey items that measure individual economic characteristics: a) economic standing of household, and b) employment status. The first item asks respondents to self-identify their households' economic position on a scale from 1 to 10, with 1 indicating the poorest households and 10 the richest. The second item asks respondents to indicate their current employment status, 1 if they are unemployed and looking for work, and 0 if otherwise. We acknowledge that respondents may have various work arrangements, including contingent and temporary work, that do not necessarily align with dichotomous categories of employed and unemployed. However, if a respondent self-indicates an unemployment status, this signals a degree of perceived economic vulnerability. This sense of perceived vulnerability is important to capture because individuals who express it may also assume that immigrants are taking jobs away from natives and, hence, hold greater AIS.

\subsection{Controls}

Based on previous research, we included whether a respondent belonged to the ethnic majority or minority. Specifically, we classified respondents as ethnic minority if their mother tongue was not the country's titular language (2010 wave) or if they did not self-identify with the titular ethnic majority (2016 wave). ${ }^{2}$ Next, to capture the influence of religion, we measured whether respondents identified as Christian or Muslim, both expressed as dichotomous variables, with 1 indicating the named religion. The omitted categories included other religions or no religion.

Additional controls included education, urban/rural residence, age, gender, marital status, and media consumption. Some studies have included the role of political narratives (Mols \& Jetten, 2014; de Oliver, 2011) and political stances (Rydgren, 2008) on immigration and refugee issues; however, valid cross-national measures of these concerns were not available in our dataset. Operationalizations are explained in Appendix 1.

\section{Results}

\subsection{Descriptive Statistics Results}

Table 1 presents descriptive statistics for all variables in the analysis. The means are reported using survey-supplied weights that render the sample means more reflective of the national populations. As shown in Figures 1 and 2, anti-immigrant sentiment markedly increased throughout the region between 2010 and 2016. The proportion of individuals across all countries who reported that they did not want immigrants as neighbors was $12.3 \%$ in 2010 , increasing to $29.5 \%$ in 2016. Each country exhibited this increasing pattern except for Albania, Bosnia, and Montenegro. These three exceptional countries have significant ethnic populations that differ from the titular ethnicity (that is, Serbs and Montenegrins in Albania; Croats and Serbs in Bosnia; and Bosnians, Albanians and Serbs in Montenegro), and each has a sizable Muslim population, which may contribute to lower average levels of anti-immigrant sentiments. (The data show the share of Muslims in Albania at 68\%, in Bosnia 57\%, and in Montenegro 15\%.)

East Europeans expressed anti-immigrant views more strongly when the issue was framed as an economic concern,

\footnotetext{
${ }^{2}$ There are some limitations to this measurement, as it may mix the distinct concepts of linguistic minority and ethnic minority. To address limitations, we examined the titular language and titular ethnicity categories of each country in the sample, bringing substantive case knowledge to bear to ensure the accuracy of this proxy measure. We used the linguistic proxy only in the 2010 survey wave in which respondents were not asked explicitly about their ethnicity.
} 
specifically, that immigrants are a burden on the national social protection system (see Figure 2). In 2010, 34.1\% of respondents across all countries held this view, an attitude that increased almost twofold to 64.9\% in 2016. Remarkably, despite the fact that these East European countries have very few non-native born residents (Eurostat, 2017, 2019) and offer limited social provisions for foreigners, the data show that East Europeans held a widespread perception in 2016 that immigrants were an economic burden.

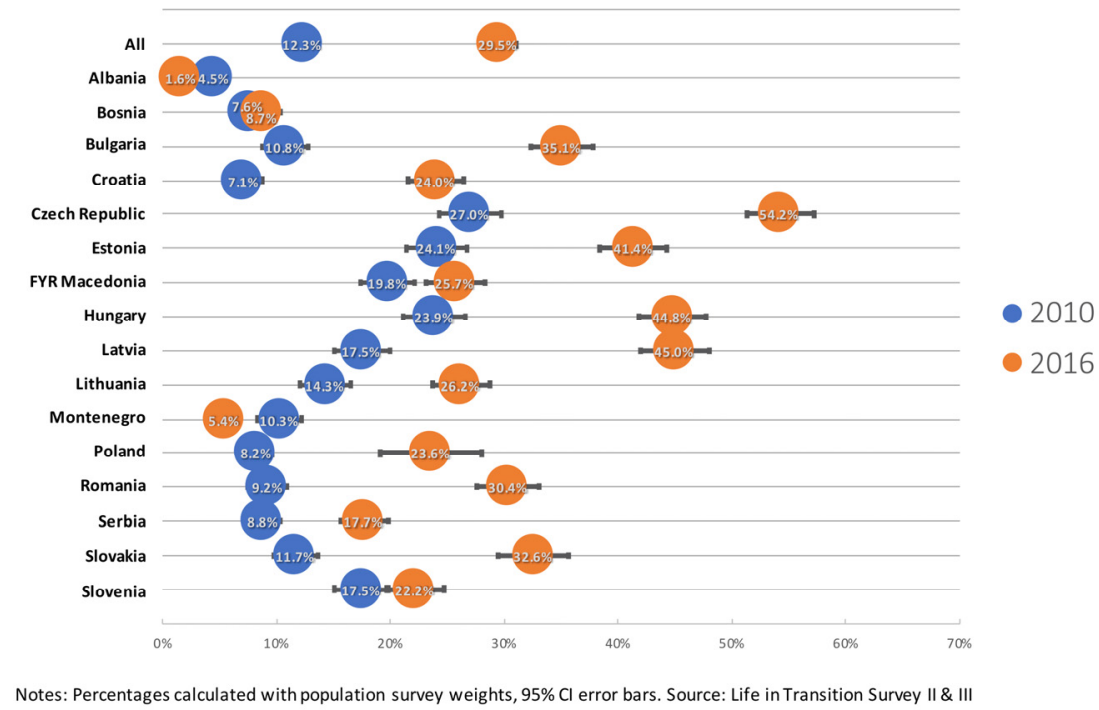

Figure 1. Percentage of Anti-Immigrant Sentiments (do not want immigrants as neighbors) in Eastern Europe in 2010 and 2016 6.2 Fixed Effects Logistic Regression Results

Table 2 includes results of the logistic regression analyses with clustered standard errors and country fixed effects. As expected (H1), anti-immigrant sentiment for both dependent variables was higher in 2016 than 2010, a change that is likely related to the increase in immigrants and asylum seekers in the EU and the ensuing political strife about accepting them. In addition, this finding was robust for both framings of the issue; that is, the coefficient for 2016 was statistically significant for both Model 1 (distaste for immigrants as neighbors) and Model 2 (perception of immigrants as an economic burden).

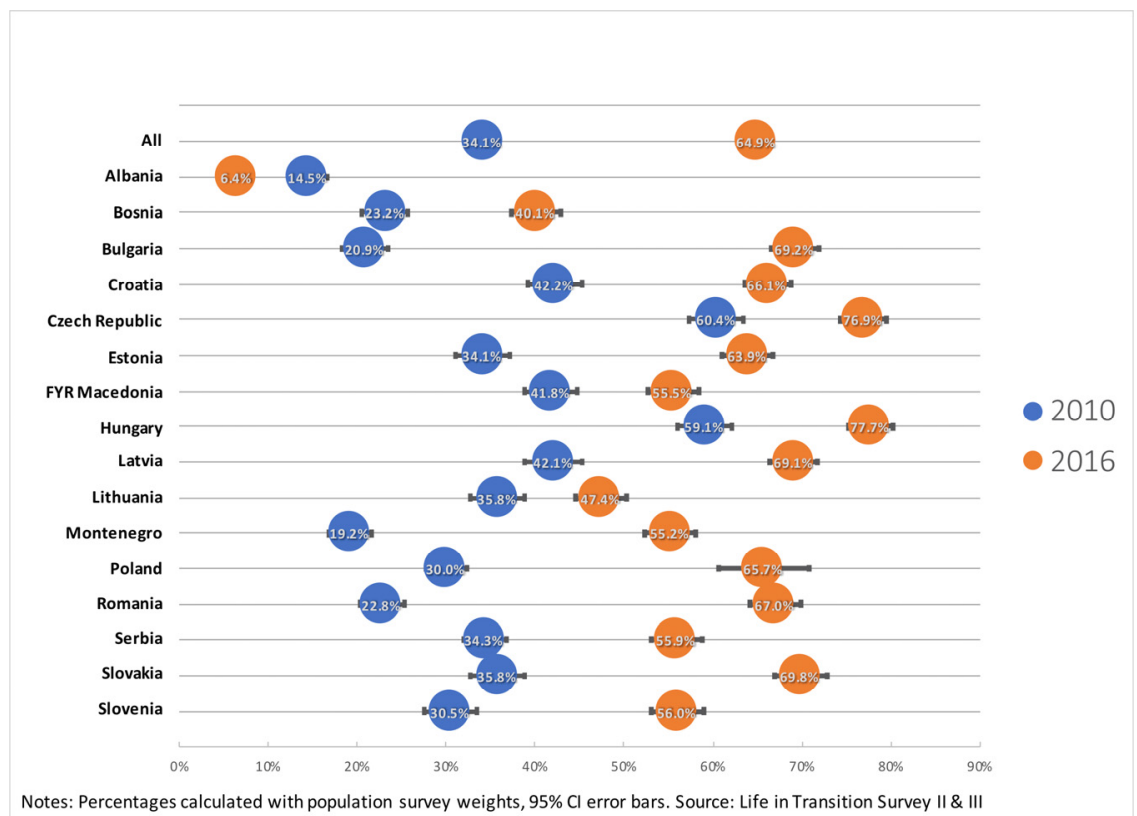

Figure 2. Percentage of Anti-Immigrant Sentiments (immigrants are a social burdent) in Eastern Europe in 2010 and 2016 
Table 2 also presents the influence of economic characteristics of individuals on their expressed anti-immigrant sentiments. Model 1 shows that economic characteristics were not significantly important when immigration was framed as a cultural problem, which fails to support hypotheses H2A and H2B. However, when immigration was framed as an economic problem (Model 2), these hypotheses were supported. In addition, lower economic standing and being unemployed were significantly associated with a greater likelihood of viewing immigrants as an economic burden, which supports H3A and H3B. Taken together, these results suggest that the way in which immigration questions are framed is particularly consequential for understanding when and how individuals express anti-immigrant sentiments.

Table 2. Logistic regression models estimating the probability of Anti-Immigrant Sentiments (AIS)

\begin{tabular}{|c|c|c|}
\hline Variables & $\begin{array}{c}\text { Model } 1 \\
\text { AIS - Neighbor }\end{array}$ & $\begin{array}{c}\text { Model } 2 \\
\text { AIS - Economic Burden }\end{array}$ \\
\hline \multicolumn{3}{|l|}{ After 2015 Refugee Crisis } \\
\hline Wave 2- 2016 & $\begin{array}{c}1.029 * * * \\
(0.117)\end{array}$ & $\begin{array}{c}1.278 * * * \\
(0.145)\end{array}$ \\
\hline \multicolumn{3}{|l|}{ Economic Characteristics } \\
\hline Economic standing & $\begin{array}{l}-0.0107 \\
(0.0128)\end{array}$ & $\begin{array}{l}-0.0366^{*} \\
(0.0177)\end{array}$ \\
\hline Unemployed & $\begin{array}{l}0.00789 \\
(0.0524)\end{array}$ & $\begin{array}{c}0.184^{*} \\
(0.0853)\end{array}$ \\
\hline \multicolumn{3}{|l|}{ Socio-Demographics } \\
\hline Ethnic minority & $\begin{array}{l}-0.0499 \\
(0.0986)\end{array}$ & $\begin{array}{c}-0.296 * * \\
(0.103)\end{array}$ \\
\hline Christian & $\begin{array}{c}0.122+ \\
(0.0734)\end{array}$ & $\begin{array}{l}0.259 * * * \\
(0.0761)\end{array}$ \\
\hline Muslim & $\begin{array}{c}-0.547 * * * \\
(0.116)\end{array}$ & $\begin{array}{l}-0.721^{*} \\
(0.301)\end{array}$ \\
\hline Education & $\begin{array}{c}-0.0711 * * * \\
(0.0141)\end{array}$ & $\begin{array}{c}-0.0791 * * * \\
(0.0170)\end{array}$ \\
\hline Age & $\begin{array}{c}0.00175 \\
(0.00136)\end{array}$ & $\begin{array}{l}0.00246+ \\
(0.00126)\end{array}$ \\
\hline Female & $\begin{array}{l}-0.0129 \\
(0.0253)\end{array}$ & $\begin{array}{l}-0.0125 \\
(0.0234)\end{array}$ \\
\hline Married & $\begin{array}{c}0.0389 \\
(0.0455)\end{array}$ & $\begin{array}{l}0.0806 * * \\
(0.0273)\end{array}$ \\
\hline Urban & $\begin{array}{l}-0.129 * \\
(0.0579)\end{array}$ & $\begin{array}{l}-0.0249 \\
(0.0619)\end{array}$ \\
\hline Media consumption & $\begin{array}{l}0.0452+ \\
(0.0274)\end{array}$ & $\begin{array}{c}0.0635 \\
(0.0472)\end{array}$ \\
\hline Total observations $(\mathrm{N})$ & 39,946 & 39,946 \\
\hline
\end{tabular}

Source: EBRD Life in Transition Survey II and III.

Notes: Coefficients shown as log odds. Robust standard errors in parenthesis. All models use country fixed effects and robust standard errors clustered by country. $* * * p<0.001, * * p<0.01, * p<0.05,+p<0.1$, two-tailed tests.

The impact of other covariates on AIS also differed across the two different question framings (Table 2). In Model 1, on having immigrants as neighbors, we found no significant relationship between expressed AIS and whether a respondent was an ethnic minority or a Christian; however, being Muslim had a significant negative correlation with respondents' expressed AIS. This relationship could point to Muslims having feelings of religious solidarity with recent immigrants, many of whom came from the Middle East and North Africa, especially after 2015.

In Model 2, which framed immigration as an economic problem, cultural considerations mattered. Specifically, ethnic minorities and Muslim respondents were less inclined to view immigrants as an economic burden, and Christians were more likely to do so. Taken together, these results emphasize that the way in which immigration questions are framed is consequential to who expresses anti-immigrant sentiments.

On the whole, these results show the sheer extent of increasing AIS in Eastern Europe between 2010 and 2016; however, the analysis at the individual level underscores the importance of how immigration questions are framed. Specifically, a 
respondent's economic positionality was a relevant predictor of attitudes when immigration was framed as an economic problem, but less so when framed as a cultural problem. Table 3 offers a truncated summary of the logistic regression results in light of the hypotheses.

Table 3. Summary of Findings (Country Fixed Effects Logistic Regression)

\begin{tabular}{|l|l|l|}
\hline $\begin{array}{l}\text { Hypothesized effect of AIS; } \\
\text { effect direction: positive (+), } \\
\text { negative (-) }\end{array}$ & $\begin{array}{c}\text { DV1: Not Want } \\
\text { Immigrants as } \\
\text { Neighbors }\end{array}$ & $\begin{array}{c}\text { DV2: Immigrants } \\
\text { are Burden to Social } \\
\text { System }\end{array}$ \\
\hline Year 2016 (+) & yes (+) & yes (+) \\
\hline Economic Standing (-) & NS & yes (-) \\
\hline Unemployment (+) & NS & yes (+) \\
\hline
\end{tabular}

$\mathrm{NS}=$ not statistically significant effect

\section{Discussion}

The influx of migrants to Europe, which began in late 2014 and has been called the 2015 European refugee crisis (Chouliaraki et al., 2017), placed immigration at the center of European politics and public discourse. The migration added to the multifaceted debate around whether governments should embrace or reject nationalist tendencies of exclusion (Bonikowski, 2017) and can be seen as part and parcel of the political and cultural backlash stemming from longer-term structural and generational changes (Inglehart \& Norris, 2017; Norris \& Inglehart, 2019). In this context, when and how people express anti-immigrant sentiments are important to understand.

Using data from EBRD's Life in Transition Survey including 16 East European countries in 2010 and 2016, we examined how anti-immigrant attitudes of East Europeans may be shaped by external contextual factors and by the way in which immigration issues are framed, either as an economic or as a cultural concern. The aim was not to establish which country-level structural conditions impact individual-level attitudes (e.g. Schlueter, Meuleman, \& Davidov, 2013). A sample of 16 countries provide only a few degrees of freedom, which limits the number of macro-level covariates that could be controlled (Möhring, 2012). Instead, our analysis relied on a statistical model using a country fixed effects logistic regression analysis, with country clustered errors, which accounted for country-level characteristics. This strategy eliminated the variance associated with time invariant country-level predictors and focused instead on the changes in the sociopolitical climate between 2010 and 2016. These changes were important to examine because of the concrete immigration pressures in Europe during 2015 and the negative reactions from East European governments to those pressures.

Indeed, our results show significant increases in anti-immigrant sentiment in 2016 compared with 2010. Almost two thirds of East European respondents to the LITS agreed that immigrants were a burden on their country's social system. Admittedly, our analysis does not conclusively establish that this significant increase in AIS is linked to the events of 2015; nevertheless, a strong case can be made that those events were particularly consequential. For instance, no other major immigration-related changes occurred in this period for all 16 East European countries examined, and several scholars have established that the 2015 immigration situation in Europe was represented as a crisis (Bellardi et al., 2018; Chouliaraki \& Zaborowski, 2017; Zaborowski \& Georgiou, 2019). Media portrayals have alluded to the need to protect native populations from potential dangers, including terrorism from Muslim invaders infiltrating countries under cover of asylum seeking (Chouliaraki et al., 2017). The backlash of East European governments against the EU directive to accept a certain quota of refugees (Baczynska, 2017; Eurostat, 2018; Kosztolanyi \& Cullen, 2018) also likely contributed to AIS. For all these reasons, the events of 2015 were potentially quite influential on individual perceptions of immigration, and our logistic regression results were consistent with this interpretation.

In addition, this study underscored the importance of how immigration survey questions are framed. The results showed that significantly more East Europeans expressed negative sentiments when the immigration question was posed as an economic problem rather than a cultural one. In addition, a respondent's economic positionality was a relevant predictor of AIS when immigration was framed as an economic problem (a burden on state's resources), but not when it was framed as a social concern (a distaste for immigrants as neighbors).

This study cannot directly address why anti-immigrant sentiments were stronger for East Europeans when the issue was framed as an economic problem; however, recent studies concerning the confluence of economic and cultural factors (Wherry, 2012; Zelizer, 2011) offer suggestions, as do analyses that theorize about economic as moral concerns (Fourcade \& Healy, 2007). Specifically, researchers have highlighted that the institutionalization of capitalism in the post-socialist 
region of Europe was not only a structural transformation, but also a moral project (Bandelj, 2016; cf. Hann, 2002), with the dominant feature of an "embrace of greed and self-interest as legitimate motives for action" (Bandelj, 2016, p. 90). The implication here is that those who find themselves in an economically vulnerable position, including immigrants seeking economic refuge, have only themselves to blame for their disadvantage and do not deserve social system support. Indeed, in a multilevel logistic regression analysis of 26 European countries based on Eurobarometer 2007 data, Kallio and Niemela (2014) showed that East Europeans were significantly more likely than West Europeans to blame individuals themselves for their poverty rather than call out the role of structural factors. Likewise, in a qualitative study of inequality beliefs among East Germans and Czechs regarding their career trajectories after 1989, Hilmar (2019) found that most research participants made moral claims when they attributed responsibility for economic circumstances to individuals rather than the system. The research participants believed that "one gets what one deserves," and they emphasized the importance of keeping "a boundary towards those considered "undeserving" (Hilmar, 2019, p. 11-12).

Although immigrants were not the focus of either Kallio and Niemela's (2014) or Hilmar's (2019) studies, they are likely to fit the category of an "undeserving population" (i.e. unworthy of common economic resources), especially in a region ripe with long-term ethnic nationalism (Bandelj \& Finley, 2016; Ekiert \& Hanson, 2003). Moreover, these findings are consistent with analyses from other world regions concerning the ways in which individuals inflect economic issues with evaluations of moral worth and deservingness (Bandelj \& Lanuza, 2018; Frye, 2012; Hilmar, 2019; Young, 2004).

Notably, our study reveals increasingly negative attitudes toward immigrants among East Europeans despite the fact that these countries have low numbers of immigrants and foreign-born residents (Wallace 2002), especially compared with other EU countries (Eurostat, 2017, 2019). In reality, immigrants are unlikely to be a heavy burden on these countries' social systems. Nevertheless, such a perception looms large in the region, especially after 2015-a perception that seems to be entwined with moral beliefs of economic deservingness rather than economic realities.

\section{Conclusion}

This study focused on how exogenous events and the framing of immigration questions may influence anti-immigration attitudes in East European post-socialist countries. An analysis of EBRD's Life in Transition data in 2010 and 2016 from 16 East European countries revealed three main findings. First, anti-immigrant sentiments were greater when immigration was presented as an economic problem (e.g. immigrants as a burden on state social services) than as a cultural one (e.g. distaste for having immigrants as neighbors). Second, no matter which way the issue was framed, anti-immigrant sentiment significantly increased from 2010 to 2016, as indicated by logistic regression with country-level fixed effects. Third, the multivariate analyses showed, net of covariates, that the respondents' economic characteristics (self-assessed economic standing and employment status) significantly shaped their AIS when the issue was framed as an economic problem, but less so when framed as a cultural problem. This result indicates that there are important scope conditions to the prevalent economic threat theory in explaining anti-immigrant attitudes.

On the whole, this study highlights the importance of context and framing in understanding when and how people express anti-immigrant sentiments. The trends observed were conditioned on actual external circumstances-immigrant pressures on European borders in 2015, media framing of such events, and the political backlash of East European governments. In addition, AIS depended on social circumstance, which renders certain identity factors more or less salient to an individual (cf. Kallio \& Niemela, 2014). Finally, the analysis points to the strong role of framing (Benford \& Snow, 2000; Goffman, 1986; Snow, Rochford, Worden, \& Benford, 1986), or the substantive focus (e.g. cultural or economic) of questions about immigrants. Frames provide a filter for complicated social issues and help individuals make sense of their experiences and observations. The findings show that hostility towards immigrants was expressed more readily when East European respondents were primed to understand the issue through an economic lens rather than a cultural one. We link the apparent salience of economic concerns in this set of East European countries to the post-socialist transition as a moral project (Bandelj, 2016), which establishes economic criteria as paramount for evaluating who is deserving in society. Therefore, this study opens the door for future research to investigate the connections between economic realities and moral meanings on other country cases, and with qualitative evidence that would yield insights into the mechanisms underlying the statistical associations we observe in our quantitative data. Such research would be all the more important because, as this study shows, the strong perception among East Europeans that immigrants are an economic burden is divorced from the reality of minimal state spending on sparse immigrant populations in these countries.

With regards to potential policy implications, our study shows that rhetorical framing of issues matters significantly for public perceptions. If East European law makers and other public figures seek to reduce social hostility directed toward immigrant groups and asylum seekers, they might best achieve their aims by emphasizing the ways in which immigration to an area can yield beneficial economic activity to counter the perception of immigration as a drain on economic resources. Furthermore, policy makers may also soften negative attitudes by working to bring popular perceptions more in 
line with the reality, in our case, of quite minimal spending on immigrant populations as a proportion of state budgets.

In the end, these findings of contextual contingency and malleability of expressed opinions on immigration in surveys emphasize that a one-side examination of the phenomenon (e.g. conducted only in unsettled times or framed only in economic terms, for instance) could lead to very skewed general understandings of individual-level predictors of anti-immigrant sentiments. Furthermore, use of decontextualized findings on immigrant attitudes can easily provide ammunition for pundits and political figures to use to advance their particular interests. Ultimately, such behavior stokes dangerous hatred between groups. We would like to believe that our central finding, that anti-immigrant attitudes are malleable, points to the opposite possibility - the hopeful potential to construct collective understandings of our society as diverse and inclusive.

\section{Acknowledgement}

We gratefully acknowledge the Center for the Study of Democracy at the University of California, Irvine, for a seed grant to support this project, and the Center for Advanced Study in the Behavioral Sciences at Stanford where the first author held a fellowship while the article was completed. We thank Debra Boka for research assistance and Katie Bolzendahl, Sara Goodman, Ruben Rumbaut, Jeff Kopstein, Graeme Boushey, and Seti Mahmoudi for their helpful comments and feedback.

\section{References}

Abeywickrama, R. S., Laham, S. M., \& Crone, D. L. (2018). Immigration and Receiving Communities: The Utility of Threats and Emotions in Predicting Action Tendencies toward Refugees, Asylum-Seekers and Economic Migrants. The Journal of Social Issues; New York, 74(4), 756-773. http://dx.doi.org/10.1111/josi.12297

Alvarez-Galvez, J. (2014). Media Exposure and Attitudes towards Immigrants. Revista Espanola de Investigaciones Sociologicas, 145, 3-24. http://dx.doi.org/10.5477/cis/reis.145.3

Anderson, J. E. (2017). Trust in Government and Willingness to Pay Taxes in Transition Countries. Comparative Economic Studies, 59(1), 1-22. https://doi.org/10.1057/s41294-016-0017-x

Andersen, J. G., \& Bjørklund, T. (2016). Structural Changes and New Cleavages: The Progress Parties in Denmark and Norway: Acta Sociologica. https://doi.org/10.1177/000169939003300303

Ariely, G. (2013). Nationhood across Europe: The Civic-Ethnic Framework and the Distinction between Western and Eastern Europe. Perspectives on European Politics and Society, 14(1), 123-143. https://doi.org/10.1080/15705854.2012.732391

Baczynkska, G. (2017, December 6). EU to sue Poland, Hungary, Czech Republic in top court over migration. Reuters. https://www.reuters.com/article/uk-europe-migrants-easterners-idUKKBN1E02VB

Bail, C. A. (2008). The Configuration of Symbolic Boundaries against Immigrants in Europe. American Sociological Review, 73(1), 37-59. https://doi.org/10.1177/000312240807300103

Baker, J. O., Perry, S. L., \& Whitehead, A. L. (2020). Keep America Christian (and White): Christian Nationalism, Fear of Ethnoracial Outsiders, and Intention to Vote for Donald Trump in the 2020 Presidential Election. Sociology of Religion. https://doi.org/10.1093/socrel/sraa015

Bandelj, N. (2016). On Postsocialist capitalism. Theory and Society, 45(1), 89-106. https://doi.org/10.1007/s11186-016-9265-z

Bandelj, N., \& Finley, K. (2016). Eastern Europe. In J. Stone, D. Rutledge, P. Rizova, A. Smith \& X. Hou (Eds.), The Wiley Blackwell Encyclopedia of Race, Ethnicity, and Nationalism. John Wiley \& Sons, Ltd.

Bandelj, N., \& Finley, K. (2019). East European Discontent. Problems of Post-Communism, 6(5), 356-368. https://doi.org/10.1080/10758216.2018.1484668

Bandelj, N., \& Lanuza, Y. R. (2018). Economic Expectations of Young Adults. Socius: Sociological Research for a Dynamic World, 4, 237802311879595. https://doi.org/10.1177/2378023118795953

Bandelj, N., \& Mahutga, M. C. (2010). How Socio-Economic Change Shapes Income Inequality in Post-Socialist Europe. Social Forces, 88(5), 2133-2161. https://doi.org/10.1353/sof.2010.0042

Bellardi, N., Busch, B., Hassemeer, J., Peissl, H., \& Scifo, S. (2018). Spaces of Inclusion-An Explorative Study on Needs of Refugees and Migrants in the Domain of Media Communication and on Responses by Community Media. Council of Europe.

Benford, R. D., \& Snow, D. A. (2000). Framing Processes and Social Movements: An Overview and Assessment. Annual Review of Sociology, 26(1), 611-639. https://doi.org/10.1146/annurev.soc.26.1.611 
Berry, M., Garcia-Blanco, I., \& Moore, K. (2016). Press Coverage of the Refugee and Migrant Crisis in the EU: A Content Analysis of Five European Countries [Project Report]. United Nations High Commissioner for Refugees (UNHCR). Retrieved from http://www.unhcr.org/56bb369c9.html

Block, F. L., \& Somers, M. R. (2016). The Power of Market Fundamentalism: Karl Polanyi's Critique. Harvard University Press.

Bohman, A. (2011). Articulated Antipathies: Political Influence on Anti-immigrant Attitudes. International Journal of Comparative Sociology, 52(6), 457-477. https://doi.org/10.1177/0020715211428182

Bohman, A., \& Hjerm, M. (2013). How the Religious Context Affects the Relationship between Religiosity and Attitudes towards Immigration. Ethnic and Racial Studies, 37(6), 937-957. https://doi.org/10.1080/01419870.2012.748210

Bohman, A., \& Hjerm, M. (2016). In the Wake of Radical Right Electoral Success: A Cross-country Comparative Study of Anti-immigration Attitudes over Time. Journal of Ethnic and Migration Studies, 42(11), 1729-1747. https://doi.org/10.1080/1369183X.2015.1131607

Bonikowski, B. (2016). Nationalism in Settled Times. Annual Review of Sociology, 42(1), 427-449. https://doi.org/10.1146/annurev-soc-081715-074412

Bonikowski, B. (2017). Ethno-nationalist Populism and the Mobilization of Collective Resentment. The British Journal of Sociology, 68(S1), S181-S213. https://doi.org/10.1111/1468-4446.12325

Brubaker, R. (1992). Citizenship and Nationhood in France and Germany. Harvard University Press.

Brubaker, R. (2017). Between Nationalism and Civilizationism: The European Populist Moment in Comparative Perspective. Ethnic and Racial Studies, 40(8), 1191-1226. https://doi.org/10.1080/01419870.2017.1294700

Ceobanu, A. M., \& Escandell, X. (2008). East is West? National Feelings and Anti-immigrant Sentiment in Europe. Social Science Research, 37(4), 1147-1170.

Ceobanu, A. M., \& Escandell, X. (2010). Comparative Analyses of Public Attitudes Toward Immigrants and Immigration Using Multinational Survey Data: A Review of Theories and Research. Annual Review of Sociology, 36(1), 309-328. https://doi.org/10.1146/annurev.soc.012809.102651

Chandler, C. R., \& Tsai, Y. (2001). Social Factors Influencing Immigration Attitudes: An Analysis of Data from the General Social Survey. The Social Science Journal, 38(2), 177-188. https://doi.org/10.1016/S0362-3319(01)00106-9

Chouliaraki, L., Georgiou, M., \& Zaborowski, R. (2017). The European "Migration Crisis" and the Media: A Cross-European Press Content Analysis. The London School of Economics and Political Science. http://eprints.lse.ac.uk/id/eprint/84670

Chouliaraki, L., \& Zaborowski, R. (2017). Voice and Community in the 2015 Refugee Crisis: A Content Analysis of News Coverage in Eight European Countries. International Communication Gazette. https://doi.org/10.1177/1748048517727173

Coenders, D. M., \& Scheepers, P. (2008). Changes in Resistance to the Social Integration of Foreigners in Germany 1980-2000: Individual and Contextual Determinants. Journal of Ethnic and Migration Studies, 34(1), 1-26. https://doi.org/10.1080/13691830701708809

Coenders, M., \& Scheepers, P. (2003). The Effect of Education on Nationalism and Ethnic Exclusionism: An International Comparison. Political Psychology, 24(2), 313-343. https://doi.org/10.1111/0162-895X.00330

Cojocaru, A. (2014a). Prospects of Upward Mobility and Preferences for Redistribution: Evidence from the Life in Transition Survey. European Journal of Political Economy, 34, 300-314. https://doi.org/10.1016/j.ejpoleco.2014.03.003

Cojocaru, A. (2014b). Fairness and Inequality Tolerance: Evidence from the Life in Transition Survey. Journal of Comparative Economics, 42(3), 590-608. https://doi.org/10.1016/j.jce.2014.01.003

Cojocaru, A., \& Diagne, M. F. (2015). How Reliable and Consistent are Subjective Measures of Welfare in Europe and Central Asia? Economics of Transition and Institutional Change, 23(1), 75-103. https://doi.org/10.1111/ecot.12056

Davidov, E., Meuleman, B., Billiet, J., \& Schmidt, P. (2008). Values and Support for Immigration: A Cross-Country Comparison. European Sociological Review, 24(5), 583-599. https://doi.org/10.1093/esr/jcn020

Davidov, E., \& Semyonov, M. (2017). Attitudes toward Immigrants in European Societies. International Journal of Comparative Sociology, 58(5), 359-366. https://doi.org/10.1177/0020715217732183 
de la Garza, R., DeSipio, L., Garcia, F., Garcia, J., \& Falcon, A. (1992). Latino Voices: Mexican, Puerto Rican, and Cuban Perspectives on American Politics. Westview Press.

DG Migration and Home Affairs. (2015). Evaluation of the Dublin III Regulation. European Commission. https://ec.europa.eu/home-affairs/sites/homeaffairs/files/what-we-do/policies/asylum/examination-of-applicants/do cs/evaluation_of_the_dublin_iii_regulation_en.pdf

Djankov, S., Nikolova, E., \& Zilinsky, J. (2016). The Happiness Gap in Eastern Europe. Journal of Comparative Economics, 44(1), 108-124. https://doi.org/10.1016/j.jce.2015.10.006

EBRD. (2020). Life in Transition Survey. //www.ebrd.com/what-we-do/economic-research-and-data/data/lits.html

Ekiert, G., \& Hanson, S. E. (Eds.). (2003). Capitalism and Democracy in Central and Eastern Europe: Assessing the Legacy of Communist Rule. Cambridge University Press.

Facchini, G., \& Mayda, A. M. (2009). Does the Welfare State Affect Individual Attitudes toward Immigrants? Evidence across Countries. The Review of Economics and Statistics, 91(2), 295-314. https://doi.org/10.1162/rest.91.2.295

Fallon, K. (2018, September 2). Three years on from Alan Kurdi's death and life is no better for child refugees in Europe. The Independent. https://www.independent.co.uk/voices/aylan-kurdi-death-three-year-anniversary-child-refugee-home-office-a85182 76.html

Fetzer, J. S. (2000a). Public Attitudes toward Immigration in the United States, France, and Germany. Cambridge University Press.

Fetzer, J. S. (2000b). Economic Self-interest or Cultural Marginality? Anti-immigration Sentiment and Nativist Political Movements in France, Germany and the USA. Journal of Ethnic and Migration Studies, 26(1), 5-23. https://doi.org/10.1080/136918300115615

Frye, M. (2012). Bright Futures in Malawi's New Dawn: Educational Aspirations as Assertions of Identity. American Journal of Sociology, 117(6), 1565-1624. https://doi.org/10.1086/664542

Gerber, A. S., Huber, G. A., Biggers, D. R., \& Hendry, D. J. (2017). Self-Interest, Beliefs, and Policy Opinions: Understanding How Economic Beliefs Affect Immigration Policy Preferences. Political Research Quarterly, 70(1), 155-171. https://doi.org/10.1177/1065912916684032

Goffman, E. (1986). Frame Analysis: An Essay on the Organization of Experience. Northeastern University Press.

Goode, E., \& Ben-Yehuda, N. (1994). Moral Panics: Culture, Politics, and Social Construction. Annual Review of Sociology, 20(1), 149-171. https://doi.org/10.1146/annurev.so.20.080194.001053

Gorodzeisky, A., \& Semyonov, M. (2009). Terms of Exclusion: Public Views towards Admission and Allocation of Rights to Immigrants in European Countries. Ethnic and Racial Studies, 32(3), 401-423. https://doi.org/10.1080/01419870802245851

Gorodzeisky, A., \& Semyonov, M. (2016). Not only Competitive Threat but also Racial Prejudice: Sources of Anti-Immigrant Attitudes in European Societies. International Journal of Public Opinion Research, 28(3), 331-354. https://doi.org/10.1093/ijpor/edv024

Grigoryan, L. K., \& Ponizovskiy, V. (2018). The Three Facets of National Identity: Identity Dynamics and Attitudes toward Immigrants in Russia. International Journal of Comparative Sociology, 59(5-6), 403-427. https://doi.org/10.1177/0020715218806037

Guriev, S., \& Melnikov, N. (2018). Happiness Convergence in Transition Countries. Journal of Comparative Economics, 46(3), 683-707. https://doi.org/10.1016/j.jce.2018.07.003

Habibov, N., Auchynnikava, A., \& Luo, R. (2019). Does Community Level Trust Improve Self-Rated Welfare? Social Indicators Research, 146(3), 669-697. https://doi.org/10.1007/s11205-019-02139-3

Hainmueller, J., \& Hiscox, M. J. (2007). Educated Preferences: Explaining Attitudes Toward Immigration in Europe. International Organization, 61(2), 399-442. https://doi.org/10.1017/S0020818307070142

Hann, C. M. (2002). Postsocialism: Ideals, Ideologies, and Practices in Eurasia. Routledge. $\mathrm{http} / / /$ www.dawsonera.com/depp/reader/protected/external/AbstractView/S9780203428115

Hare, P. G., \& Turley, G. (Eds.). (2013). Handbook of the Economics and Political Economy of Transition. Routledge.

Hayes, B. C., \& Dowds, L. (2006). Social Contact, Cultural Marginality or Economic Self-Interest? Attitudes Towards Immigrants in Northern Ireland. Journal of Ethnic and Migration Studies, 32(3), 455-476. 
https://doi.org/10.1080/13691830600554890

Hilmar, T. (2019). The Temporal Logic of Deservingness: Inequality Beliefs in Two Postsocialist Societies. Socius, 5, 2378023119864231. https://doi.org/10.1177/2378023119864231

Hjerm, D. M. (2007). Do Numbers Really Count? Group Threat Theory Revisited. Journal of Ethnic and Migration Studies, 33(8), 1253-1275. https://doi.org/10.1080/13691830701614056

Hjerm, M. (1998). National Identities, National Pride and Xenophobia: A Comparison of Four Western Countries. Acta Sociologica, 41(4), 335-347. https://doi.org/10.1177/000169939804100403

Hjerm, M. (2001). Education, Xenophobia and Nationalism: A Comparative Analysis. Journal of Ethnic and Migration Studies, 27(1), 37-60. https://doi.org/10.1080/13691830124482

Inglehart, R. (1977). The Silent Revolution: Changing Values and Political Styles Among Western Publics (Princeton Legacy Library Edition 2016). Princeton University Press.

Inglehart, R., \& Norris, P. (2017). Trump and the Populist Authoritarian Parties: The Silent Revolution in Reverse. Perspectives on Politics, 15(2), 443-454. https://doi.org/10.1017/S1537592717000111

Kallio, J., \& Niemelä, M. (2014). Who Blames the Poor? European Societies, 16(1), 112-135. https://doi.org/10.1080/14616696.2013.787435

Kešić, J., \& Duyvendak, J. W. (2019). The Nation under Threat: Secularist, Racial and Populist Nativism in the Netherlands. Patterns of Prejudice, 53(5), 441-463. https://doi.org/10.1080/0031322X.2019.1656886

Kitschelt, H., \& McGann, A. J. (1997). The Radical Right in Western Europe: A Comparative Analysis. University of Michigan Press.

Korosteleva, J., \& Stępien-Baig, P. (2020). Climbing the Poverty Ladder: The Role of Entrepreneurship and Gender in Alleviating Poverty in Transition Economies. Entrepreneurship \& Regional Development, 32(1-2), 197-220. https://doi.org/10.1080/08985626.2019.1640482

Kosztolanyi, B., \& Cullen, S. (2018, June 21). Central European countries to skip migration summit as EU tries to work out refugee issue. CNN. https://www.cnn.com/2018/06/21/europe/hungary-slovakia-poland-czech-skip-migration-summit-intl/index.html

Krippner, G. R., \& Alvarez, A. S. (2007). Embeddedness and the Intellectual Projects of Economic Sociology. Annual Review of Sociology, 33(1), 219-240. https://doi.org/10.1146/annurev.soc.33.040406.131647

Lamont, M. (1992). Money, Morals and Manners. University of Chicago Press.

Lamont, M., \& Molnár, V. (2002). The Study of Boundaries in the Social Sciences. Annual Review of Sociology, 28(1), 167-195. https://doi.org/10.1146/annurev.soc.28.110601.141107

Mahutga, M. C., \& Bandelj, N. (2009). Foreign Investment and Income Inequality: The Natural Experiment of Central and Eastern Europe. International Journal of Comparative Sociology, 49(6), 429-454. https://doi.org/10.1177/0020715208097788

Marozzi, M. (2016). Construction, Robustness Assessment and Application of an Index of Perceived Level of Socio-Economic Threat from Immigrants: A Study of 47 European Countries and Regions. Social Indicators Research, 128(1), 413-437. https://doi.org/10.1007/s11205-015-1037-z

Mayda, A. M. (2006). Who Is Against Immigration? A Cross-Country Investigation of Individual Attitudes toward Immigrants. The Review of Economics and Statistics, 88(3), 510-530. https://doi.org/10.1162/rest.88.3.510

Meuleman, B., Davidov, E., \& Billiet, J. (2009). Changing Attitudes toward Immigration in Europe, 2002-2007: A Dynamic Group Conflict Theory Approach. Social Science Research, 38(2), 352-365. https://doi.org/10.1016/j.ssresearch.2008.09.006

Möhring, K. (2012, October). The Fixed Effects Approach as Alternative to Multilevel Models for Cross-national Analyses. GK SOCLIFE Working Papers Series. The 10th ESPAnet Conference, Edinburgh, Scotland. http://www.soclife.uni-koeln.de/fileadmin/wiso_fak/gk_soclife/pdf/Working_papers/KMoehring_2012a_ssrn_the_ fixed_effects.pdf

Mols, F., \& Jetten, J. (2014). No Guts, No Glory: How Framing the Collective Past Paves the Way for Anti-immigrant Sentiments. International Journal of Intercultural Relations, 43, 74-86. https://doi.org/10.1016/j.ijintrel.2014.08.014

Nikolova, E., \& Sanfey, P. (2016). How Much should we Trust Life Satisfaction Data? Evidence from the Life in 
Transition Survey. Journal of Comparative Economics, 44(3), 720-731. https://doi.org/10.1016/j.jce.2015.11.003

Norris, P., \& Inglehart, R. (2019). Cultural Backlash: Trump, Brexit, and the Rise of Authoritarian-populism. Cambridge University Press.

Oliver, M. de. (2011). Nativism and the Obsolescence of Grand Narrative: Comprehending the Quandary of Anti-Immigration Groups in the Neoliberal Era. Journal of Ethnic and Migration Studies, 37(7), 977-997. https://doi.org/10.1080/1369183X.2011.559029

Palmer, D. L. (1996). Determinants of Canadian Attitudes toward Immigration: More than Just Racism? Canadian Journal of Behavioural Science / Revue Canadienne Des Sciences Du Comportement, 28(3), 180-192. https://doi.org/10.1037/0008-400X.28.3.180

Pardos-Prado, S. (2011). Framing Attitudes Towards Immigrants in Europe: When Competition Does Not Matter. Journal of Ethnic and Migration Studies, 37(7), 999-1015. https://doi.org/10.1080/1369183X.2011.572421

Pehrson, S., Vignoles, V. L., \& Brown, R. (2009). National Identification and Anti-Immigrant Prejudice: Individual and Contextual Effects of National Definitions. Social Psychology Quarterly, 72(1), 24-38. https://doi.org/10.1177/019027250907200104

Pichler, F. (2010). Foundations of Anti-immigrant Sentiment: The Variable Nature of Perceived Group Threat across Changing European Societies, 2002-2006. International Journal of Comparative Sociology, 51(6), 445-469. https://doi.org/10.1177/0020715210379456

Polavieja, J. G. (2016). Labour-market Competition, Recession and Anti-immigrant Sentiments in Europe: Occupational and Environmental Drivers of Competitive Threat. Socio-Economic Review, 14(3), 395-417. https://doi.org/10.1093/ser/mww002

Quillian, L. (1995). Prejudice as a Response to Perceived Group Threat: Population Composition and Anti-Immigrant and Racial Prejudice in Europe. American Sociological Review, 60(4), 586-611. JSTOR. https://doi.org/10.2307/2096296

Ray, J., Pugliese, A., \& Esipova, N. (2017, September 6). EU Most Divided in World on Acceptance of Migrants. Gallup.Com. https://news.gallup.com/poll/217841/divided-world-acceptance-migrants.aspx

Rydgren, J. (2008). Immigration Sceptics, Xenophobes or Racists? Radical Right-wing Voting in Six West European Countries. European Journal of Political Research, 47(6), 737-765. https://doi.org/10.1111/j.1475-6765.2008.00784.x

Sanfey, P. (2011). People and Transition. In P. Hare \& G. Turley (Eds.), Handbook of the Economics and Political Economy of Transition. Routledge. https://doi.org/10.4324/9780203067901.ch25

Scheppele, K. L. (2014, May 6). Hungary and the End of Politics. The Nation. https://www.thenation.com/article/hungary-and-end-politics/

Schlueter, E., Meuleman, B., \& Davidov, E. (2013). Immigrant Integration Policies and Perceived Group Threat: A Multilevel Study of 27 Western and Eastern European Countries. Social Science Research, 42(3), 670-682. https://doi.org/10.1016/j.ssresearch.2012.12.001

Schmidt, P., \& Quandt, M. (2018). National Identity, Nationalism, and Attitudes toward Migrants in Comparative Perspective. International Journal of Comparative Sociology, 59(5-6), 355-361. https://doi.org/10.1177/0020715218816242

Schneider, I. (2017). Can We Trust Measures of Political Trust? Assessing Measurement Equivalence in Diverse Regime Types. Social Indicators Research, 133(3), 963-984. https://doi.org/10.1007/s11205-016-1400-8

Schneider, S. L. (2008). Anti-Immigrant Attitudes in Europe: Outgroup Size and Perceived Ethnic Threat. European Sociological Review, 24(1), 53-67. https://doi.org/10.1093/esr/jcm034

Semyonov, M., \& Glikman, A. (2009). Ethnic Residential Segregation, Social Contacts, and Anti-Minority Attitudes in European Societies. European Sociological Review, 25(6), 693-708. https://doi.org/10.1093/esr/jcn075

Semyonov, M., Raijman, R., \& Gorodzeisky, A. (2006). The Rise of Anti-foreigner Sentiment in European Societies, 1988-2000. American Sociological Review, 71(3), 426-449. https://doi.org/10.1177/000312240607100304

Semyonov, M., Raijman, R., \& Gorodzeisky, A. (2007). On the Relations Between Right-Wing Parties and Anti-foreigner Sentiment. American Sociological Review, 72(5), 841-849. https://doi.org/10.1177/000312240707200510

Semyonov, M., Raijman, R., \& Gorodzeisky, A. (2008). Foreigners' Impact on European Societies: Public Views and 
Perceptions in a Cross-National Comparative Perspective. International Journal of Comparative Sociology, 49(1), 5-29. https://doi.org/10.1177/0020715207088585

Semyonov, Moshe, Raijman, R., Tov, A. Y., \& Schmidt, P. (2004). Population Size, Perceived Threat, and Exclusion: A Multiple-indicators Analysis of Attitudes toward Foreigners in Germany. Social Science Research, 33(4), 681-701. https://doi.org/10.1016/j.ssresearch.2003.11.003

Shin, H., \& Dovidio, J. F. (2018). Differences, Threats, Values, and Country-Specific Prejudice toward Immigrants and Foreign Workers in Three Major Receiving Countries: The United States, Germany, and Australia. The Journal of Social Issues; New York, 74(4), 737-755. http://dx.doi.org/10.1111/josi.12296

Sides, J., \& Citrin, J. (2007). European Opinion About Immigration: The Role of Identities, Interests and Information. British Journal of Political Science, 37(3), 477-504. https://doi.org/10.1017/S0007123407000257

Simon, R. J. (1993). Old Minorities, New Immigrants: Aspirations, Hopes, and Fears. The ANNALS of the American Academy of Political and Social Science, 530(1), 61-73. https://doi.org/10.1177/0002716293530001005

Smale, A., \& Eddy, M. (2015, August 31). Migrant Crisis Tests Core European Value: Open Borders. The New York Times. https://www.nytimes.com/2015/09/01/world/europe/austria-migrant-crisis-truck.html

Snow, D. A., Rochford, E. B., Worden, S. K., \& Benford, R. D. (1986). Frame Alignment Processes, Micromobilization, and Movement Participation. American Sociological Review, 51(4), 464-481. https://doi.org/10.2307/2095581

Spoor, M., Tasciotti, L., \& Peleah, M. (2014). Quality of Life and Social Exclusion in Rural Southern, Central and Eastern Europe and the CIS. Post-Communist Economies, 26(2), 201-219. https://doi.org/10.1080/14631377.2014.904107

Tertytchnaya, K., Vries, C. E. D., Solaz, H., \& Doyle, D. (2018). When the Money Stops: Fluctuations in Financial Remittances and Incumbent Approval in Central Eastern Europe, the Caucasus and Central Asia. American Political Science Review, 112(4), 758-774. https://doi.org/10.1017/S0003055418000485

Tilly, C. (2004). Social Boundary Mechanisms. Philosophy of the Social Sciences, 34(2), 211-236. https://doi.org/10.1177/0048393103262551

Tkalec, M. (2020). History Matters: Development and Institutional Persistence of the Habsburg Military Frontier in Croatia. Public Sector Economics, 44(1), 117-145. https://doi.org/10.3326/pse.44.1.4.

Wallace, C. (2002). Opening and Closing Borders: Migration and Mobility in East Central Europe. Journal of Ethnic and Migration Studies, 28(4), 603-625.

Wherry, F. F. (2012). The Culture of Markets. Polity.

Wilkes, R., \& Corrigall-Brown, C. (2011). Explaining Time Trends in Public Opinion: Attitudes towards Immigration and Immigrants. International Journal of Comparative Sociology, 52(1-2), 79-99. https://doi.org/10.1177/0020715210379460

Wilkes, R., Guppy, N., \& Farris, L. (2008). "No Thanks, We're Full”: Individual Characteristics, National Context, and Changing Attitudes toward Immigration. International Migration Review, 42(2), 302-329. https://doi.org/10.1111/j.1747-7379.2008.00126.x

Young, A. A. (2006). The Minds of Marginalized Black Men: Making Sense of Mobility, Opportunity, and Future Life Chances. Princeton University Press. https://doi.org/10.1515/9781400841479

Zaborowski, R., \& Georgiou, M. (2019). Gamers versus Zombies? Visual Mediation of the Citizen/Non-citizen Encounter in Europe's 'Refugee Crisis.' Popular Communication, 17(2), 92-108. https://doi.org/10.1080/15405702.2019.1572150

Zelizer, V. (2011). Economic Lives: How Culture Shapes the Economy. Princeton University Press.

Zubrzycki, G. (2001). "We, the Polish Nation": Ethnic and Civic Visions of Nationhood in Post-Communist Constitutional Debates. Theory and Society, 30(5), 629-668. 


\section{Appendix I. Variables used in the Analysis}

\begin{tabular}{|c|c|}
\hline Survey Item & Survey Wording and Coding Strategy \\
\hline $\begin{array}{l}\text { Does not want immigrants as } \\
\text { neighbors }\end{array}$ & $\begin{array}{l}\text { On this list are various groups of people. Could you please mention any that } \\
\text { you would not like to have as neighbours[sic]? } \\
\text { Immigrants/foreign workers listed among } 15 \text { options. Binary coded as } 1= \\
\text { Respondent indicated immigrants/foreign workers and } 0=\text { did not select } \\
\text { immigrants/foreign workers. }\end{array}$ \\
\hline $\begin{array}{l}\text { Views immigrants as a burden } \\
\text { on the social protection system }\end{array}$ & $\begin{array}{l}\text { Of the following statements, which is the one that is closest to your opinion } \\
\text { on immigrants? } \\
\text { - Immigrants make a valuable contribution to the national economy of } \\
\text { our country } \\
\text { - Immigrants are a burden for the national social protection system } \\
\text { - None of the above } \\
\text { - Do not know } \\
\text { Binary coded as } 1=\text { Immigrants are a burden for the national social } \\
\text { protection system and } 0=\text { Any other response }\end{array}$ \\
\hline Economic standing & $\begin{array}{l}\text { Please imagine a ten-step ladder where on the bottom, the first step, stand } \\
\text { the poorest } 10 \% \text { and on the highest step, the tenth, stand the richest } 10 \% \text {. On } \\
\text { which step of the ten is your household today? }(2010 \& 2016) \\
\text { [Respondent marks } 1-10]\end{array}$ \\
\hline $\begin{array}{l}\text { Unemployed [and looking for } \\
\text { job] }\end{array}$ & $\begin{array}{l}\text { Did you work during the past } 12 \text { months? Are you actively looking for a job } \\
\text { at this moment? } \\
\text { Binary coded as } 1=\text { No work in past } 12 \text { months \& actively looking for a job } \\
\text { at this moment and } 0=\text { Any other combination of responses }\end{array}$ \\
\hline Ethnic minority & $\begin{array}{l}\text { What is your ethnicity? (2016) } \\
\text { What is your mother tongue? (2010) } \\
\text { Binary coded as } 1=\text { not identified as majority ethnicity (2016) or mother } \\
\text { tongue not titular language (2010) and } 0=\text { of majority ethnicity (2016) or } \\
\text { titular language (2010) }\end{array}$ \\
\hline Christian/Muslim & $\begin{array}{l}\text { What is your religion? } \\
-\quad \text { Atheistic/Agnostic/None } \\
-\quad \text { Buddhist } \\
-\quad \text { Jewish } \\
-\quad \text { Orthodox Christian } \\
-\quad \text { Catholic } \\
-\quad \text { Other Christian, Including Protestant } \\
\text { - } \quad \text { Muslim } \\
\text { - Other } \\
\text { Christian coded } 1=\text { Orthodox Christian, Catholic, or other Christian } \\
\text { including Protestant and } 0=\text { All other responses } \\
\text { Muslim coded } 1=\text { Muslim and } 0=\text { All other responses }\end{array}$ \\
\hline Education & $\begin{array}{l}\text { What is the highest level of education you already completed? (2010) } \\
\text { What is the highest education level [PR] has completed? (2016) } \\
\text { - } \quad \text { No degree / No education } \\
\text { - } \quad \text { Primary Education }(2010 \& 2016) \\
\text { - } \quad \text { Lower secondary education }(2010 \& 2016) \\
\text { - } \quad \text { (Upper) secondary education } \\
\text { - } \quad \text { Post-secondary non-tertiary education }(2010 \& 2016) \\
\text { - } \quad \text { Tertiary education }(2010 \& 2016)\end{array}$ \\
\hline
\end{tabular}




\begin{tabular}{|c|c|}
\hline & $\begin{array}{l}\text { - } \quad \text { Bachelor's degree or more }(2010 \& 2016) \\
\text { - } \quad \text { Master's degree or PhD }(2010 \& 2016) \text { Post-graduate degree (2006) } \\
\text { Coded on scale of } 1 \text { (No degree/education) to } 7 \text { (2010) or } 8 \text { (2016) (Master's } \\
\text { degree or PhD) }\end{array}$ \\
\hline Female & $\begin{array}{l}\text { Is }[\text { NAME }] \text { male or female? } \\
\text { Binary coded } 1=\text { Female and } 0=\text { Male }\end{array}$ \\
\hline Married & Married or cohabitating $=1,0=$ otherwise \\
\hline Media consumption & $\begin{array}{l}\text { People use different sources to learn what is going on in their country and } \\
\text { the world. For each of the following sources, please indicate how often you } \\
\text { use it: (2010 \& 2016) } \\
\text { - Never } \\
\text { - } \quad \text { About once a year } \\
\text { - } \quad \text { Several times a year } \\
\text { - } \quad \text { About once a month } \\
\text { - } \quad \text { About once a week } \\
\text { - } \quad \text { Several times a week } \\
\text { - } \quad \text { Daily } \\
\text { Sources: Newspaper; News broadcasts on radio or TV; Printed magazines; } \\
\text { In-depth reports on radio or TV; Internet or email; Talk with family, friends } \\
\text { or colleagues [omitted]; Social media (2016 only) } \\
\text { Coded using max value among all media sources listed resulting in scale of } 1 \\
\text { (never use) to } 7 \text { (daily use). }\end{array}$ \\
\hline
\end{tabular}

\section{Copyrights}

Copyright for this article is retained by the author(s), with first publication rights granted to the journal.

This is an open-access article distributed under the terms and conditions of the Creative Commons Attribution license (http://creativecommons.org/licenses/by/4.0/). 